\title{
Purification of Gastric Mucosal ECL Cells from a Crude Elutriation Fraction
}

\author{
John M. Graham, Ph.D. \\ School of Biomolecular Sciences, Liverpool John Moores University, Office address: 34, \\ Meadway, Upton, Wirral CH49 6JQ \\ E-mail: john@jgrescon.fsbusiness.co.uk
}

Received March 7, 2002; Accepted May 15, 2002; Published June 14, 2002

\begin{abstract}
Acid-secreting parietal cells from the gastric mucosa are widely studied as a model in studies on ion transport and the endocrine/paracrine ECL cells effectively control parietal cell function. Discontinuous gradients of iodixanol for the purification of ECL cells were subsequently simplified to the use of a density barrier. This technique is now commonly used following initial centrifugal elutriation.
\end{abstract}

KEY WORDS: gastric mucosa, ECL cells, OptiPrep ${ }^{\mathrm{TM}}$, iodixanol, density barrier

DOMAINS: cell biology, endocrinology, gastroenterology, immunology, clinical medicine, medical research, methods and protocols

METHOD TYPE: extraction, isolation, purification and separation

SUB METHOD TYPE: centrifugation

\section{INTRODUCTION}

Investigations into the functioning and control of cells of the gastric mucosa are important in understanding the physiological activity of this tissue in both normal and clinical conditions. They have however a broader significance, since the gastric mucosa is widely recognized as an important model system for studying the functioning and control of any secretory epithelium.

Probably the most intensively studied cell is the acid-secreting parietal cell as this provides a very useful model for studying both the regulation of ion-transport and intracellular signaling pathways[1]. ECL cells are the main endocrine/paracrine cell type and they play an important role in controlling acid secretion[2].

This Protocol Article will describe the purification of ECL cells. The purification of parietal and chief cells is presented in a companion Protocol Article[3]. 
ECL cells have been purified by repeated centrifugal elutriation followed by banding in a discontinuous iodixanol gradient[1]. Subsequently the two layer discontinuous gradient was simplified to a density barrier[2] and it is this method that is presented in this Protocol Article.

\section{MATERIALS AND EQUIPMENT}

OptiPrep $^{\mathrm{TM}}(60 \% \mathrm{w} / \mathrm{v}$, iodixanol)

OptiPrep $^{\mathrm{TM}}$ diluent: $60 \mathrm{mg} / \mathrm{ml}$ BSA, $7.2 \mathrm{mM} \mathrm{MgCl} 2,90 \mathrm{mM}$ Hepes-NaOH pH 7.4

OptiPrep $^{\mathrm{TM}}$ Working Solution (WS) of $50 \%(\mathrm{w} / \mathrm{v})$ iodixanol: mix 5 vol of OptiPrep ${ }^{\mathrm{TM}}$ with 1 vol of Solution B

WS Diluent: $10 \mathrm{mg} / \mathrm{ml} \mathrm{BSA}, 140 \mathrm{mM} \mathrm{NaCl}, 1.2 \mathrm{mM} \mathrm{MgSO}_{4}, 1 \mathrm{mM} \mathrm{CaCl}_{2}, 0.5 \mathrm{mM}$ DTT, $1 \mathrm{mM}$ glucose, $15 \mathrm{mM}$ Hepes-NaOH, pH 7.4

Plastic conical centrifuge tubes $(12-15 \mathrm{ml})$

Syringe with metal cannula or plastic Pasteur pipette

Low-speed (temperature-controlled) centrifuge with swinging-bucket rotor

\section{METHOD}

1. Disperse the gastric mucosal cells by Pronase digestion[4].

2. Partially purify the ECL cells by centrifugal elutriation[1].

3. Dilute WS with the WS Diluent to produce a solution of $10.8 \%(\mathrm{w} / \mathrm{v})$ iodixanol (approx. equivalent to $\rho=1.061 \mathrm{~g} / \mathrm{ml}$ ).

4. Layer $1 \mathrm{ml}$ of the ECL cell containing suspension $\left(2 \times 10^{6}\right.$ cells $)$ over $10 \mathrm{ml}$ of the iodixanol solution in a $15-\mathrm{ml}$ centrifuge tube (see Note 1 ).

5. Centrifuge at $1,000 \mathrm{rpm}$ for $5 \mathrm{~min}$ (at speed), using slow acceleration $\left(400 \mathrm{rpm} \cdot \mathrm{min}^{-1}\right.$ ) and no brake during deceleration.

6. The ECL cells band just above the $10.8 \%$ iodixanol layer (see Fig. 1).

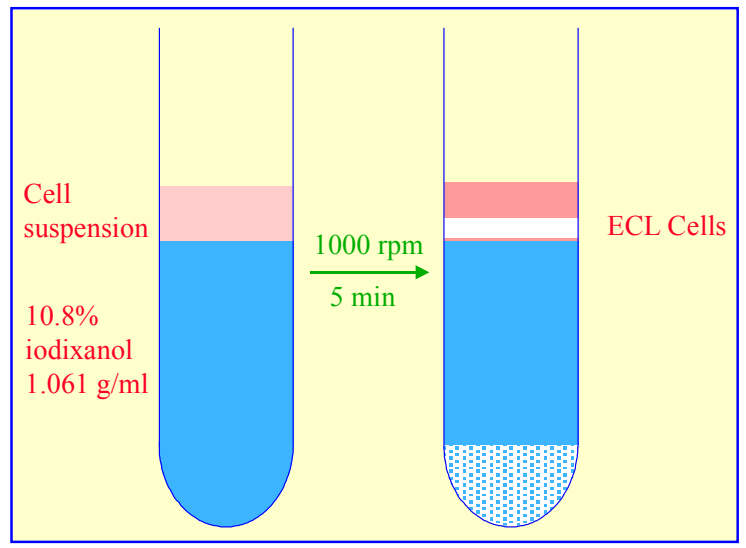

FIGURE 1. Isolation of gastric ECL cells on an iodixanol density barrier. 


\section{NOTES}

As this method isolates the least dense cell from a mixed population containing denser cells, it may be worthwhile considering an alternative flotation strategy. The cells should be suspended in a $15 \%(\mathrm{w} / \mathrm{v})$ iodixanol solution (dilute WS with WS Diluent) and layered beneath the $10.8 \%$ iodixanol solution. This flotation strategy has been used very successfully for the isolation of other low-density cells from tissue digests (e.g., $[5,6])$.

\section{ACKNOWLEDGEMENTS}

The author and TheScientificWorld wish to thank Axis-Shield PoC, AS, Oslo, Norway for their kind permission to adapt OptiPrep ${ }^{\mathrm{TM}}$ Application Sheet C31 in the preparation of this Protocol Article.

\section{REFERENCES}

1. Lindström, E., Lerner, U.H., and Håkanson, R. (2001) Isolated rat stomach ECL cells generate prostaglandin $\mathrm{E}_{2}$ in response to interleukin-1 $\beta$, tumor necrosis factor- $\alpha$ and bradykinin. Eur. J. Pharmacol. 416, 255-263.

2. Lindström, E. and Håkanson, R. (2001) Neurohormonal regulation of secretion from isolated rat stomach ECL cells: a critical reappraisal. Regul. Pept. 97, 169-180.

3. Graham, J.M. (2002) Purification of parietal and chief cells from the gastric mucosa. TheScientificWorldJOURNAL 2, in press.

4. Lindström, E., Björkqvist, M., Boketoft, A., Chen, D., Zhao, C.-M., and Håkanson, R. (1997) Neurohormonal regulation of histamine and pancreastatin secretion from isolated rat stomach ECL cells. Regul. Pept. 71, 73-86.

5. Graham, J.M. (2002) Purification of Islets of Langerhans from porcine pancreas. TheScientificWorldJOURNAL 2, in press.

6. Graham, J.M. (2002) Fractionation of hepatic non-parenchymal cells. TheScientificWorldJOURNAL 2, $1347-1350$.

This article should be referenced as follows:

Graham, J.M. (2002) Purification of gastric mucosal ECL cells from a crude elutriation fraction. TheScientificWorldJOURNAL 2, 1643-1645. 

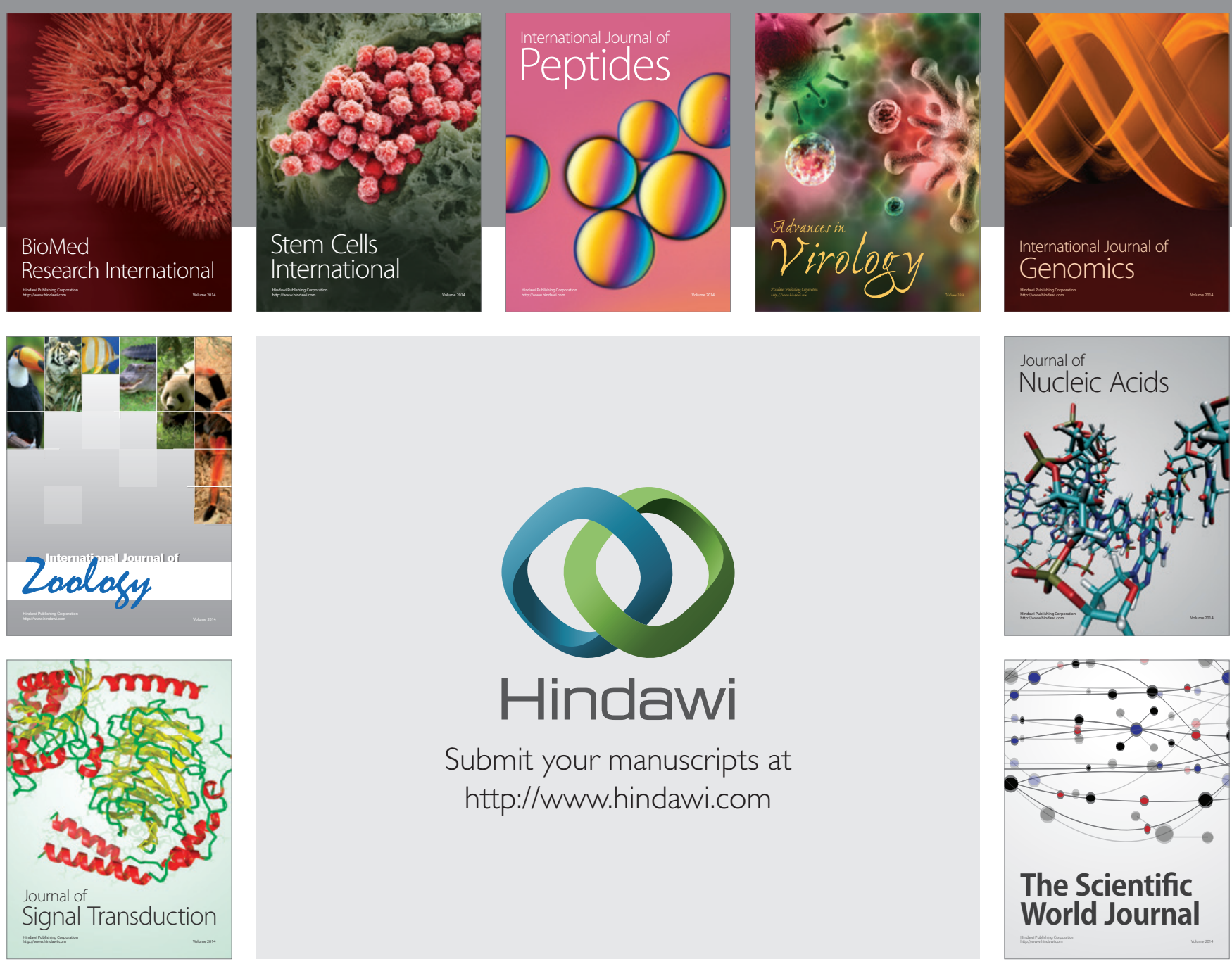

Submit your manuscripts at

http://www.hindawi.com
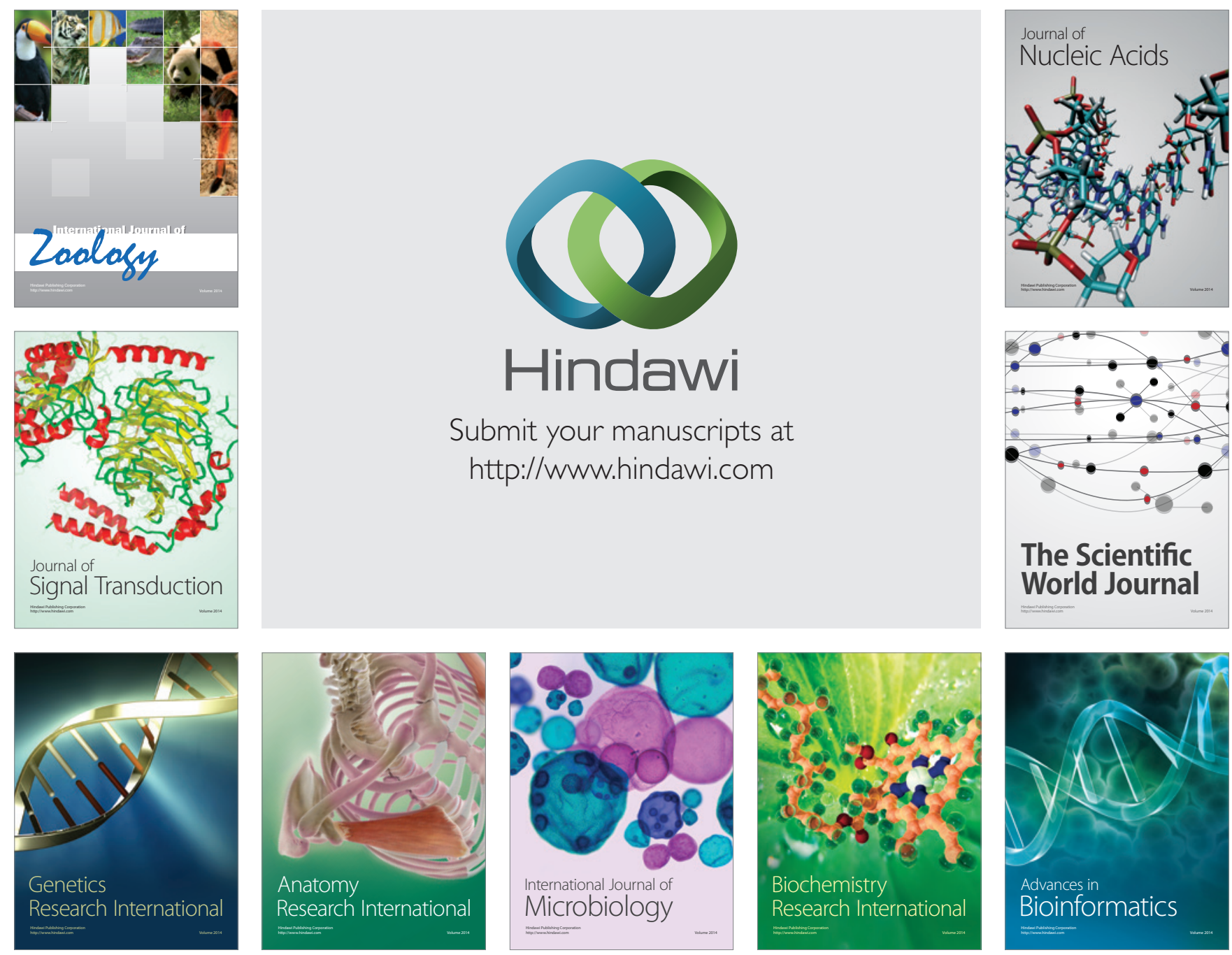

The Scientific World Journal
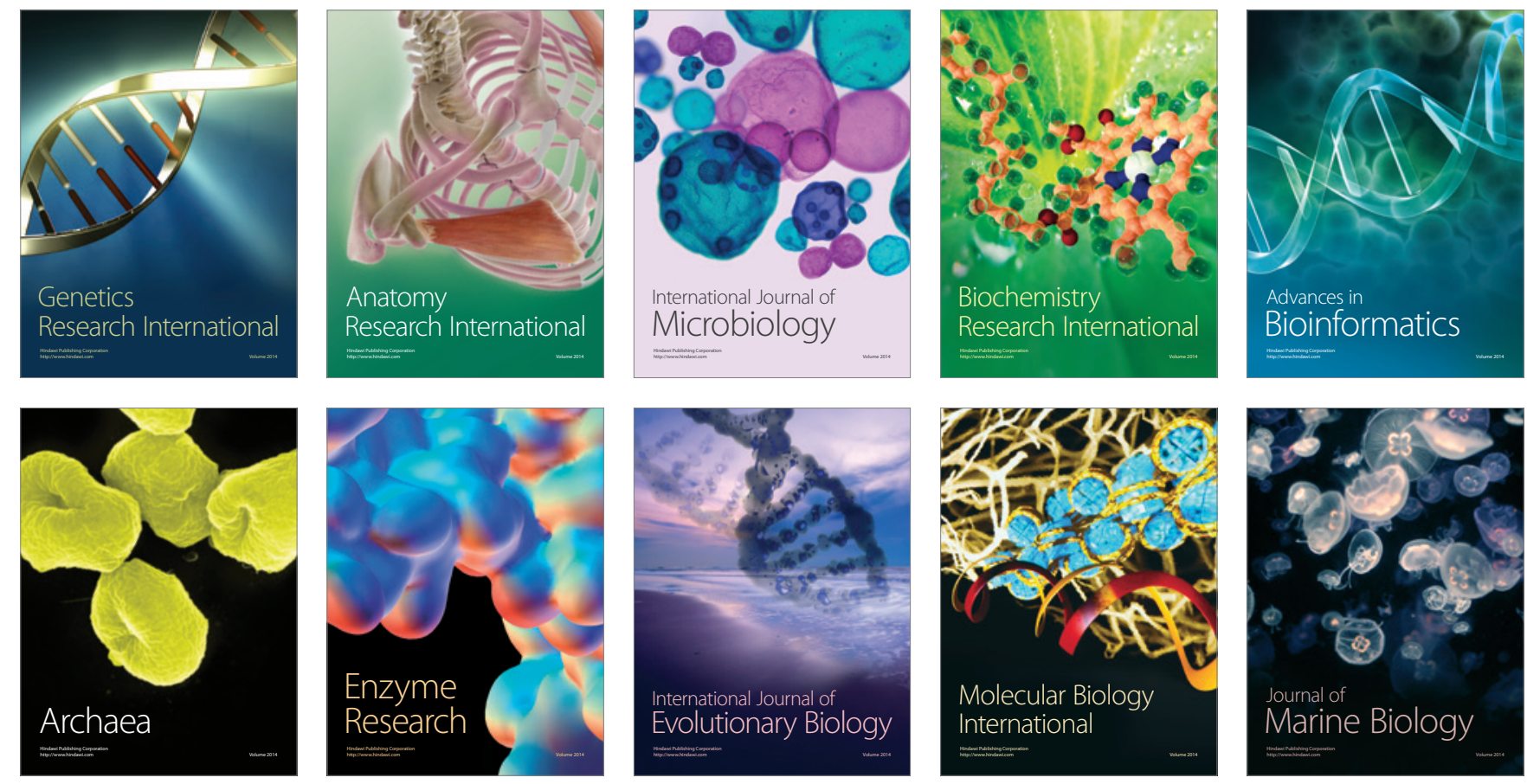